\title{
Youth Justice in Europe: Experience of Germany, the Netherlands, and Croatia in Providing Developmentally Appropriate Responses to Emerging Adults in the Criminal Justice System
}

\section{Sibella Matthews, Vincent Schiraldi \& Lael Chester}

To cite this article: Sibella Matthews, Vincent Schiraldi \& Lael Chester (2018): Youth Justice in Europe: Experience of Germany, the Netherlands, and Croatia in Providing Developmentally Appropriate Responses to Emerging Adults in the Criminal Justice System, Justice Evaluation Journal, DOI: 10.1080/24751979.2018.1478443

To link to this article: https://doi.org/10.1080/24751979.2018.1478443

进 Published online: 31 Jul 2018.

Submit your article to this journal $\sqsubset$

Џ Article views: 494

View Crossmark data ¿ 


\title{
Youth Justice in Europe: Experience of Germany, the Netherlands, and Croatia in Providing Developmentally Appropriate Responses to Emerging Adults in the Criminal Justice System
}

\author{
Sibella Matthews ${ }^{a}$, Vincent Schiraldi ${ }^{b}$ and Lael Chester

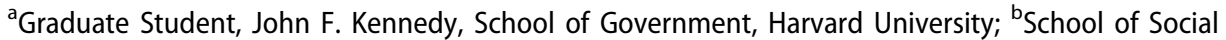 \\ Work \& Justice Lab, Columbia University; 'Justice Lab, Columbia University
}

\begin{abstract}
There is a growing awareness, in the United States and Europe, that emerging adults - those ages 18-25 - are a developmentally distinct group worth special treatment at the hands of the justice system. Four US states have proposed raising the age of their juvenile courts' jurisdiction beyond age 18 within the last year, while four out of five European countries have special laws affecting emerging adults. Three European nations - Croatia, Germany, and the Netherlands - allow youth over age 18 to be sanctioned in the same manner as younger youth in the juvenile justice system, including the possibility of being housed in juvenile facilities. In March 2018, the Columbia University Justice Lab sponsored an educational delegation of 20 elected and appointed officials, legal system stakeholders, service providers, and advocates to Germany to learn more about the German approach to emerging adults. In advance of that delegation, the authors in this article examined the law and practice regarding court-involved emerging adults in Croatia, Germany, and the Netherlands to glean potential lessons for US policy-makers considering a developmentally distinct approach to emerging adults in their justice systems.
\end{abstract}

\section{ARTICLE HISTORY}

Received 27 April 2018

Accepted 9 May 2018

\section{KEYWORDS}

Crime; Europe; justice; reform; youth

\section{Introduction}

As many US states begin to propose and even implement justice reforms targeted specifically at emerging adults ${ }^{1}$ (ages 18-25), the time is ripe for an examination of the laws and practices in Europe, where Germany, the Netherlands, and Croatia all provide interesting models for consideration.

There has been a growing recognition in the United States that the justice system is failing this age cohort and, in turn, compromising public safety. Nationally, emerging

CONTACT Lael Chester lec2115@columbia.edu

${ }^{1}$ In the context of European justice systems, this age group (ages 18-25) is most often referred to as "young adults," and in the United States, it is also often referred to as "transition-age youth." The authors have chosen to use the term "emerging adults" in this paper, a term first coined by American psychologist Jeffrey Arnett in 2000, because it reflects the fact that this transitory developmental period, between childhood and adulthood, is an ongoing process rather than a stagnant label. 
adults constitute a disproportionate number of people arrested and incarcerated and have the highest postprison recidivism rates of any age cohort (Chester \& Perker, 2017, p. 2). There is also a growing body of research in neurobiology and psychology indicating that the cognitive skills and emotional intelligence that mark the transition from childhood to adulthood continue to develop at least into a person's mid-20s (Giedd et al., 1999, pp. 861-863; Howell et al., 2013). Many of the traits so prominent among adolescents - notably their high susceptibility to peer pressure, marked proneness to risk-taking and impulsive behavior, and tendency to be overly motivated by reward seeking behavior - are also prevalent among emerging adults (Bryan-Hancock \& Casey, 2010; Monahan, Steinberg, Cauffman, \& Mulvey, 2009). Researchers have pointed to these characteristics in regard to the proclivity of youth to engage in criminal behavior (Monahan, Steinberg, \& Piquero, 2015). In distinguishing between children and adults, the United States Supreme Court has found these developmental markers to have constitutional significance under the Eighth Amendment's prohibition of cruel and unusual punishment and the Fifth Amendment's due process protections against self-incrimination. ${ }^{2}$

Sociological research has further contributed to a better understanding of this age group. The transitional period from child to adult - that is, from an immature and emotionally, financially and practically dependent person to an independent, mature individual - has become prolonged, with people reaching such key markers as marriage, educational milestones and meaningful employment, later than in previous generations. These milestones, in turn, are protective factors that help young people, particularly young males, mature out of delinquency and into adult roles (Schiraldi, Western, \& Bradner, 2015). All of this research is directly relevant to understanding system-involved youth, a significant number of whom manage to age-out out of criminal behavior by age 25; the age at which crime rates fall precipitously (Loeber, Farrington, \& Petechuk, 2013; Piquero, Farrington, \& Blumstein, 2003; Sampson \& Laub, 2003).

Since the creation of separate state juvenile justice systems over a hundred years ago, the criminal laws and practices in the United States for emerging adults have been remarkably consistent in one key respect: On or before the 18th birthday, youths are automatically prosecuted and sentenced as adults, with very little legal distinction between them and older, more mature adults.

There are indications that this is now being reconsidered: in 2018, the Massachusetts, Connecticut, Illinois, and Vermont legislatures have all considered bills that would raise the age of juvenile jurisdiction for most offenses (except the most serious) beyond a youth's 18th birthday. In addition, other traditionally "at-18" laws have been moving up: all states now set the legal age to purchase alcohol at 21 (Federal Trade Commission, 2013). Within the last few years, states have also started moving up the age for the purchase of tobacco from 18 to 21. As of 11 January 2018, five states - California, New Jersey, Oregon, Hawaii, and Maine - have raised the

\footnotetext{
${ }^{2}$ The following US Supreme Court decisions all include a discussion of the constitutional significance of youthfulness and immaturity for youth convicted of crimes that occurred before their 18th birthday: Roper v. Simmons, 543 U.S. 551 (2005), Graham v. Florida, 560 U.S. 48 (2010), Miller v. Alabama, 132 S.Ct. 2455 (2012) and J.D.B. v. North Carolina, $131 \mathrm{~S}$. Ct. 2394 (2011). Recently, courts have also been asked to consider whether youthfulness has constitutional significance in cases in which criminal offenses occurred after the person's 18th birthday. See e.g., People v. House, 2015 IL App (1st) 110580 (2015) (holding that that a life without parole sentence applied to a 19year-old "violates the proportionate penalty language of the constitution as applied to him").
} 
tobacco age to 21 , along with hundreds of localities across the country. ${ }^{3}$ For states that have legalized recreational marijuana, the minimum age has been set at 21 or higher (Robinson, 2018). A majority of states now allow state-funded extended foster care or extended child welfare services beyond age 18, departing from the traditional practice of ending such care at age 18 (National Conference of State Legislatures, 2017). There is, in short, a growing recognition that decisions and actions undertaken by 18-year-old high school students or 19- and 20-year-old college-aged students may be mitigated by their lack of maturity and that sanctioning them like fully mature adults could have life-long consequences that harm the youth and communities and impinge upon public safety.

Europe, in contrast, has both a history and widespread practice of providing more developmentally appropriate responses to emerging adults involved in the justice system, with 28 out of 35 European countries having special legal provisions for youth over age 18 (Pruin \& Dünkel, 2015, pp. 8-10). In summary, the European approach to emerging adults includes the following:

- 20 out of 35 countries (57\%) provide for either the application of educational measures/rehabilitation provided by juvenile law or special rules concerning specific sanctions for young adults in the general penal law.

- 18 out of 35 countries (51\%) provide special rules in the adult criminal law concerning the mitigation of penalties for young adults.

- 10 out of 35 countries (29\%) provide for the mitigation of sanctions according to the general criminal law as well as the application of juvenile law sanctions.

Germany, the Netherlands, and Croatia provide three interesting examples of these options that have gone the furthest in applying juvenile court protections to emerging adults. Although the laws and practices in these three countries differ, one theme that arises when comparing and contrasting them with the United States is the age chosen to help define such critical factors as criminal responsibility, youth court jurisdiction, youth correctional jurisdiction, type and length of sentences, and public access to criminal records. The United States prosecutes younger youths, provides more opportunities for trying and sentencing youths as adults, incarcerates youths for longer periods of time and in adult facilities, provides public access to the criminal records of youths, and often disregards the distinct developmental stage of youths transitioning from childhood to adulthood (see Monahan et al., 2015). In Germany, the Netherlands, and Croatia, each country's justice system has taken a much different approach, carving out special provisions for individuals up to their 21st (or, in the case of the Netherlands, 23rd) birthday, recognizing their ongoing maturation and development

\footnotetext{
${ }^{3}$ For a list of the ages set by states and other jurisdictions for the purchase of tobacco and tobacco products, see https://tobacco21.org and https://www.tobaccofreekids.org/assets/content/what_we_do/state_local_issues/sales_21/ states_localities_MLSA_21.pdf. In just the first two months of 2018, two other states have gotten decidedly closer to raising the age to 21: Indiana's House Public Policy Committee voted unanimously to increase the cigarette purchasing age from 18 to 21 years old (http://www.chicagotribune.com/news/nationworld/midwest/indiana/ctindiana-smoking-age-20180129-story.html), and Illinois' Senate Public Health Committee voted 6-2 to prohibit the sale of tobacco or related products to anyone under 21 (http://www.chicagotribune.com/news/nationworld/ctillinois-senate-21-tobacco-20180206-story.html).
} 
and applying factors that they believe will contribute to better outcomes and increased public safety.

\section{Youth justice in the United States}

Since the creation of the first juvenile court in Cook County, Illinois, in 1899, the United States has developed two separate systems to prosecute people accused of committing crime: a juvenile system for children and adolescents and an adult criminal justice system for all older ages. The age range for the separate juvenile system has never been firmly established. The majority of states do not specify in their laws any lower age limit for criminal responsibility while others set the age as low as 6 . Until Massachusetts passed a new law in April 2018, designating the 12th birthday as the lowest age of criminal responsibility, age 10 had been the highest minimum age set in the country ( 2 years below the international standard of age 12 ). ${ }^{4}$ The upper-age range has also not been firmly established, and there have even been different ages set for the different genders (Campaign for Youth Justice, 2016). Although there is a growing national consensus for the juvenile system to extend to youth up to their 18th birthday, laws vary across the United States. Two consistent factors have been (1) that every state tries and/or sentences some children under age 18 as adults in the adult criminal justice system (often depending on the offense alleged) and (2) that on their 18th birthday (at latest), every state automatically prosecutes and sentences youths as adults.

Although rarely publicized or researched, some states also have laws, usually called "youthful offender" provisions, that in essence constitute a hybrid of the juvenile and adult justice systems that is applied to youth usually before their 18th birthday but also sometimes after their 18th birthday. Massachusetts' youthful offender provision is an example of such a hybrid system used for some youths alleged to have committed crimes between their 14th and 18th birthdays. If the charges fall within the provision of the statute, ${ }^{5}$ a Massachusetts' prosecutor has the discretion to seek an indictment by a grand jury and prosecute the youth as a "youthful offender." The hybrid nature of these proceedings means that there is a juvenile judge that presides over the case in juvenile court, but, unlike other juvenile proceedings, these proceedings are open to the public like adult criminal court. The youth can be "adjudicated" - a term used in juvenile court - and sentenced in the juvenile correctional system to age 21, the adult correctional system for much greater periods of time, or both (given an adult sentence suspended on and after a juvenile sentence).

Other states provide a similar hybrid model for youth past their 18th birthday, including Vermont, which recently expanded its youthful offender law to apply to

\footnotetext{
${ }^{4}$ The National Juvenile Defender Center (NJDC) provides a graphic documenting the minimum age (or lack of limits) of juvenile jurisdiction in various states: http://www.jjgps.org/jurisdictional-boundaries. For a description of a time in the history of juvenile court jurisdiction in Illinois when different ages of jurisdiction were chosen for the different genders, see Willrich (2003, p. 209).

${ }^{5}$ M.G.L. chapter 119, $\S 52$ defines "youthful offender." For a detailed summary of the law and legal process, see Holly Smith and Wendy Wolf, Overview of the Law: Youthful Offender, Youth Advocacy Division, Committee for Public Counsel Services, October 2013 at https://www.publiccounsel.net/ya/wp-content/uploads/sites/6/2014/08/OVERVIEWOF-YOUTHFUL-OFFENDER-LAW.pdf
} 
youths charged with committing crimes up to their 22nd birthday (State of Vermont, 2016). Although the implications of these youthful offender statutes are different in the various states that have them, in all cases the youths are more likely to be afforded some of the protections found in juvenile systems (e.g., confidentiality of the court proceedings or criminal record) and provided rehabilitative service (e.g., placement in a juvenile facility rather than an adult jail or prison) that they would not have been provided in the adult criminal justice system.

The recent growth in interest in emerging adult justice, and the desire by policymakers and justice practitioners to find more effective ways to address the needs of emerging adults and to increase public safety, has led a number of jurisdictions in the United States to consider justice reforms. These efforts tend to fall into the following categories: (1) expansion of the hybrid, "youthful offender" provisions described above, (2) specialty courts, (3) special caseloads (e.g., probation), (4) special correctional units or facilities, (5) expansion of the age range of juvenile jurisdiction, (6) increased opportunity for sealing or expunging criminal records, and (7) special parole provisions. ${ }^{6}$

Currently, however, no state has embraced the systemic reform of including emerging adults in their juvenile justice systems as has been proposed in 2018 in Connecticut, Illinois, Massachusetts, and Vermont. While culturally distinct from the United States, Germany, the Netherlands, and Croatia provide a potential road map for those states to consider.

\section{European models of youth justice}

Worldwide there is far greater diversity among youth justice systems than adult criminal justice systems, largely due to the diversity of perspectives on childhood, youth, and adolescence (Weijers, 2017, p. 63). While laws and policies vary between each country, European youth justice systems tend to fall into two broad categories.

The first is known as the Flexible Model. The UN Committee on the Convention on the Rights of the Child holds the opinion that a special juvenile justice system must be in place for young persons until the age of 18. Despite this, several European countries have laws or policies allowing for the transfer of juvenile defendants to the adult criminal justice system known as the flexible model (as seen in Belgium and the Netherlands). However, in Europe, the transfer of juvenile defendants to the adult system is far rarer than in the United States (Rap \& Weijers, 2014, p. 92).

The second is known as the Strict Model. In this type of model, European countries fix an upper age limit of the youth justice system, and preclude the prosecution of children and young people under that age limit in the adult system under any circumstances (as seen in Germany, Greece, Italy, Spain, and Switzerland). In most strict model countries, this implies that the youth justice systems have longer maximum prison sentences, in comparison with the more moderate juvenile sentences of flexible model countries. However, in strict model countries, the court trial and execution of

\footnotetext{
${ }^{6}$ The National Institute of Justice undertook a research project to compile a list of programs and policies designed to serve justice-involved young adults across the United States. Although it is now slightly out-of-date, it is the most comprehensive list currently available: Connie Hayek, Environmental Scan of Developmentally Appropriate Criminal Justice Responses to Justice-Involved Young Adults. June 2016. Washington, D.C.: U.S. Department of Justice, National Institute of Justice. NCJ 249902. https://www.ncjrs.gov/pdffiles1/nij/249902.pdf
} 
the sentence remain the responsibility of the youth justice authorities (Rap \& Weijers, 2014, pp. 92-93).

The past three decades have seen international human rights standards catalyze youth justice reforms across Europe, including the United Nations Standard Minimum Rules for the Administration of Juvenile Justice in 1985 ("The Beijing Rules"), the Convention on the Rights of the Child in 1989, and the Council of Europe's 2003 and 2008 recommendations. These international standards have continued the momentum toward diversion, minimum intervention, education, restorative justice, and other constructive measures, even for youths prosecuted for the most serious criminal offenses. At the same time, most European countries have experienced a reduction in juvenile delinquency as well as juvenile imprisonment rates (Dünkel, 2016a, p. 681).

Applying the rehabilitative goals of the juvenile justice system to older systeminvolved youth is becoming an established norm for the European context. For example, the Council of Europe's 2003 recommendations included the following rule: "Reflecting the extended transition to adulthood, it should be possible for young adults under the age of 21 to be treated in a way comparable to juveniles and to be subject to the same interventions, when the judge is of the opinion that they are not as mature and responsible for their actions as full adults" (Council of Europe Committee of Ministers, 2003, para. 11). In effect, the Council of Europe have agreed that appropriate responses to the particular developmental needs of emerging adults can often be found in juvenile justice legislation, particularly in light of the prolonged phases of education and integration into work and family life for modern young adults (Dünkel, 2016a, p. 697).

In addition to the prolonged transition to adulthood, recent findings in neuroscience indicating that maturity and psycho-social abilities are not fully developed until the third decade of life have also been influential (Dünkel, 2016a, p. 708). For example, the authors of a Model Law on Juvenile Justice proposed by the United Nations Office of Drugs and Crime in 2013 advised that "States should note that a majority of European States have extended the applicability rationae personae of their juvenile justice laws to the age of 21 as neuro-scientific evidence and brain development studies have indicated that it is difficult to distinguish between the brain of an older child and that of a young adult" (United Nations Office of Drugs and Crime, 2013, p. 57).

While emerging adults represent a significant proportion of criminal convictions and experience high rates of recidivism, most age out of their criminal offending by their mid-20s. Given their overrepresentation in the criminal justice system, European legislators are recognizing that effectively addressing the needs of this age group is central to reducing crime (International Centre for Prison Studies, 2010, p. 2). The early success of countries like Germany, which extended the juvenile criminal law to emerging adults up to the age of 21 in 1953 has allowed other European countries to see in practice that treating young people in a manner that reflects their maturity is equally valid for juveniles as it is for emerging adults (Dünkel, 2016a, p. 708). Only seven out of 35 European countries do not have some type of special provisions for prosecuting and/or sentencing young adults (Pruin \& Dünkel, 2015, pp. 8-10).

While it has been a long-held common practice in Europe for emerging adults held in confinement to be able to remain in the juvenile prison system into their early $20 \mathrm{~s}$ 
(Pruin \& Dünkel, 2015, p. 4), recent reforms have also expanded the use of other juvenile sanctions for the emerging adult population. For example, laws in Croatia, the Czech Republic, Germany, Lithuania, the Netherlands, Portugal, Slovenia, Switzerland, and Russia allow "educational measures"7 under the juvenile criminal law to apply to young adults (Pruin \& Dünkel, 2015, p. 61). The Netherlands' 2014 reforms allowing juvenile justice sanctions to be applied to emerging adults up to the age of 23 make the Dutch system a leader in raising the age. However, the existence of the legal provisions allowing the application of juvenile sanctions to emerging adults does not guarantee extensive use in practice. While Germany applies juvenile justice sanctions in cases of system-involved emerging adults by default, the Netherlands (and other countries such as Croatia, Lithuania, and Slovenia) apply juvenile justice sanctions far less frequently (Pruin \& Dünkel, 2015, p. 62).

\section{Germany: Utilizing youth court and youth corrections}

\section{Jurisdiction of the youth justice system}

Germany's youth justice system is characterized by the approach of minimum intervention with priority given to diversion, and nonpunitive and rehabilitative responses (referred in Europe as "educational measures") (Dünkel, 2016a, p. 682). Germany applies a strict model, which means juveniles under 18 cannot be prosecuted in the adult criminal court or receive adult criminal sanctions, even where very serious offenses take place. The guiding principle of the German juvenile justice system is Erziehung (education and care), referring to the original right and duty of parents, which the state partly executes when a juvenile commits an offense.

The enactment of the Youth Courts Law (Jugendgerichtsgesetz) (JGG) in 1923 combined justice and welfare approaches, set the age of criminal responsibility at 14 years, allowed educational measures instead of punishment (particularly instead of imprisonment), and introduced the concept of prosecutorial discretion (Dünkel, 2016b; Rap \& Weijers, 2014, p. 89). Reforms in 1953, 1990, and 2008 further emphasized diversion, educational and rehabilitative sanctions, and restorative responses to youth offending (Rap \& Weijers, 2014, p. 93). The 1953 reforms allowed sanctions under the JGG to apply to 18-, 19- and 20-year-old young adults in place of the general criminal law (Dünkel, 2016b). In part, this was in response to the situation of the "fatherless generation" of young people in Germany post-World War II (Clarke, 2015). The 2008 reform clarified the overall aim of juvenile justice in Germany, that is, to prevent individual juveniles and emerging adults from committing further offenses (Dünkel, 2016b).

\footnotetext{
${ }^{7}$ The term "educational measure" is often used to embody the elements listed in Section 10 of the German Youth Courts Act, to distinguish from formal judicial interventions and incarceration. They can include such rehabilitative measures to improve youth socialization as community service, social training courses, victim-offender mediation, and vocational training. See, e.g., http://blog.globalyouthjustice.org/?p=2694. In this paper, the term "educational measures" will be replaced with a terms more commonly understood in the United States, such as "rehabilitation" and "community treatment and services."
} 
Table 1. Summary of the jurisdiction and sanctions of the Youth Court and Criminal Court in Germany.

\begin{tabular}{lll}
\hline Age at time of crime & Adjudicated by & Sanctions according to \\
\hline $14-17$ & Youth Court & Juvenile Justice \\
$18-20$ & Youth Court & Juvenile Justice (67\%) \\
& Youth Court & Adult Criminal Law (33\%) \\
21 and over & Criminal Court & Adult Criminal Law \\
\hline
\end{tabular}

\section{Emerging adults in the justice system}

In Germany, the specialized youth court has jurisdiction over juveniles between 14 and 21 years old. A summary of the jurisdiction of the youth court and adult court is shown in Table 1. Young adults from 18 up to (but not including) 21 can receive a sentence according to juvenile law or a (mitigated) sentence according to adult criminal law (Rap \& Weijers, 2014, p. 126). The procedures in the youth court are the same for young adults as they are for minors (Rap \& Weijers, 2014, p. 94). Under Section $105, J G G$, the judge is required to apply a juvenile sanction to young adults up to age 21 under one of two conditions: if the moral, psychological, and social maturity of the offender is that of a juvenile, or if the type, circumstances, or motives of the offense were typical of juvenile misconduct (International Centre for Prison Studies, 2010, p. 3).

The Federal Supreme Court has held that typical juvenile crimes are "spontaneous acts resulting from the developmental forces of juvenile age," which has included a case where a 20-year-old young adult killed his 3-month-old baby due to being angered by the baby's crying (Pruin \& Dünkel, 2015, p. 41). Furthermore, the Federal Supreme Court has ruled that a young adult has the maturity of a juvenile if his or her personality is still developing (International Centre for Prison Studies, 2010, p. 3). The youth courts are therefore tasked with considering the young adult's maturity, developmental stage, and circumstances when determining the best avenue of treatment (Ishida, 2015, p. 2).

While there is considerable variation between the states, two-thirds of young adults were sentenced as juveniles in 2012 across Germany overall compared to only $38 \%$ of young adults sentenced as juveniles in 1964 (Dünkel, 2016a, p. 708; Pruin \& Dünkel, 2015 , p. 42). Steadily, over the years, the judiciary and prosecutors have gained more faith in this approach, using the juvenile system more frequently for emerging adults. Typically, the more serious cases are retained in the juvenile jurisdiction, and minor offenses that require less justice-system involvement, such as traffic infractions, are dealt with in the adult system (International Centre for Prison Studies, 2010, p. 3). A Youth Court Judge in Berlin explained during a recent site visit with the authors that the German courts generally view it to be a benefit for society as a whole to treat young people up to age 21 in the youth system; "If there is any doubt, judges tend to apply juvenile law sanctions" (Schiraldi, 2018c).

More than half of emerging adults charged with offenses such as driving under the influence or without a license are handled in the adult system due to the presence of a procedure used to manage high caseloads, which does not exist in juvenile criminal law (traffic offenders receive a fine by way of a sentencing proposal that is sent directly from the prosecutor to the judge with no need for a hearing). As shown in 


\section{Proportion of young adult offenders sentenced under juvenile criminal law according to different offenses in Germany in 2012}

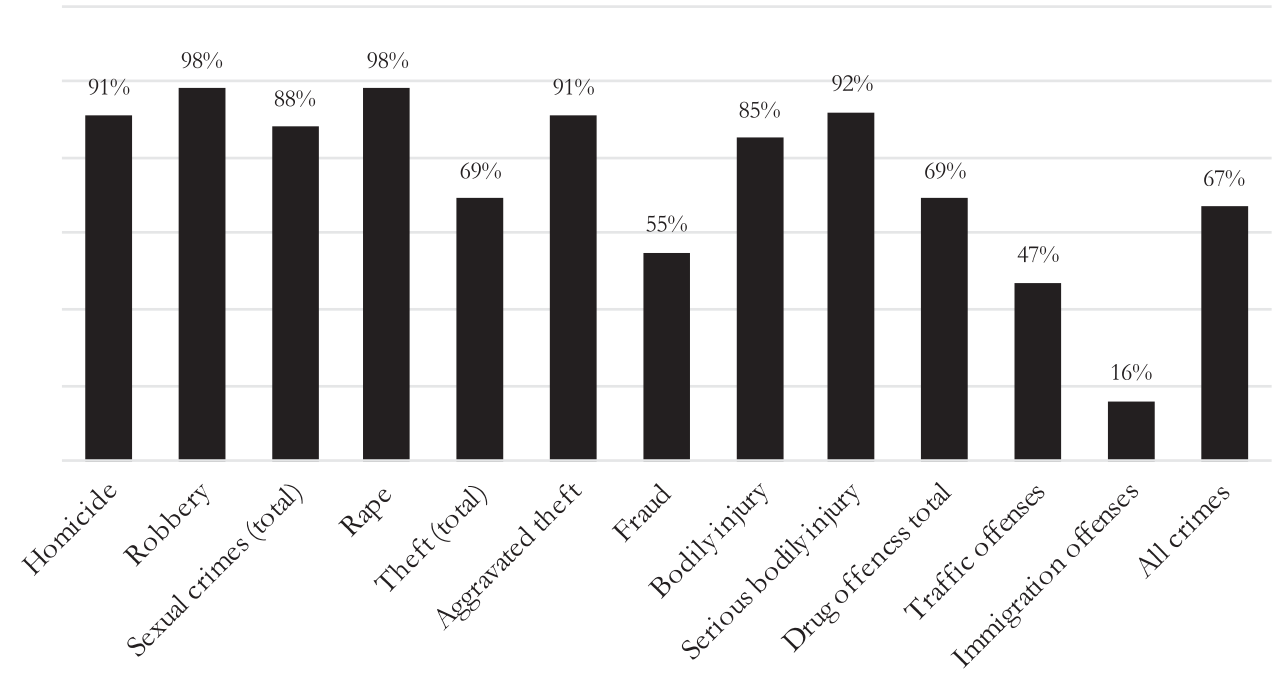

Figure 1. Adapted from Ineke Pruin and Frieder Dünkel, "Better in Europe? European Responses to Young Adult Offending" (Universitat Greifswald: Transition to Adulthood, March 2, 2015).

Figure 1, in 2012, over $90 \%$ of young adults were sentenced under the juvenile law for homicide, rape, and other serious bodily injury crimes, reflecting the confidence in the ability of the juvenile justice system to appropriately handle the most serious offenses (Pruin \& Dünkel, 2015, pp. 43-44, 46). The large number of young adults processed via the JGG is also attributable in part to the very severe (by European standards) mandatory minimum sentences for serious offenses in the adult criminal code (such as life imprisonment for an act of murder) (Rap \& Weijers, 2014, p. 94). Judges in the adult system are bound by a formal sentencing framework and the gravity of the offense with little room for individualized sentencing (however, judicial discretion in sentencing is arguably still wider in Germany than in the United States) (Pruin \& Dünkel, 2015, p. 41).

\section{Role of police, prosecutors, and the courts}

The youth justice system in Germany involves specialized youth courts, youth prosecutors, and, in major cities, specialized youth police units (Dünkel, 2016b). The specialized units, known as "Houses of Youth Justice," contain police, juvenile prosecutors, social workers, and, in some cases, mediation services, working together to find quick solutions and alternatives to detention (Dünkel \& Heinz, 2017, p. 311). The police must refer every offense to the prosecutor who can then decide to take no further action or dismiss the case when an educational measure is already in place (Rap \& Weijers, 2014 , p. 117). If the likely sentencing outcome is a non-custodial sanction, the prosecutor submits a case file to a Youth Judge at the Local Court, and can ask the judge 
to impose a minor sanction as a warning, such as community service up to $40 \mathrm{~h}$, a fine, or mediation (Dünkel, 2016b; Rap \& Weijers, 2014, p. 117).

If a youth prison sentence is being considered, the Youth Court of the Local Court is composed of one professional and two lay judges. For more serious cases, such as homicide or sexual offenses, the case is heard by the Youth Chamber at the District Court, composed of three professionals and two lay judges (Dünkel, 2016b). The lay judges are 'pedagogically capable' members of the public (one male and one female) who have equal voting rights on the guilt of the defendant and the sanction (Rap \& Weijers, 2014, p. 126). The youth has one appeal, either to the District Court for a second hearing, or the Higher Regional Court of a Federal State for a review of legal questions, which is intended to speed up trials and enforce the rehabilitative aim of juvenile justice (Dünkel, 2016b). The limited avenues of judicial review put juveniles at a disadvantage compared to the adult system from a legal and human rights perspective. For example, a court decision cannot be appealed solely on the basis of seeking a different educational measure or rehabilitative service, which is problematic when "severe" measures are imposed.

Social workers from the community youth welfare department are required to participate in the trial and prepare a social inquiry report to give evidence on the personal background of the system-involved youth and assist the court in finding an appropriate sanction (Dünkel, 2016b). In reality, this does not occur in less serious cases due to welfare departments being overburdened (Dünkel, 2016b). In the case of young adults, social workers provide the youth court with recommendations concerning the application of adult or juvenile criminal law (Rap \& Weijers, 2014, p. 133).

\section{Diversion, confinement, and other penalties}

Youth court sanctions are seen as a last resort, with priority given to diversion, followed by educational, rehabilitative or disciplinary measures ordered by the youth courts instead of imprisonment (Dünkel, 2016b). Approximately $70 \%$ of the juvenile and system-involved youth adults are diverted, with youth imprisonment used only rarely ( $2 \%$ of all cases involving juveniles and young adults) (Dünkel, 2016a, p. 702, 2016b).

Because of the historical abuse of police power under the Nazi regime, diversion can only be exercised by the prosecutor or the Youth Court Judge with no restriction on the types/nature of the offenses that are eligible for diversion (Dünkel, 2016b). Even felony offenses can be diverted under certain circumstances, such as where the youth has made an apology or repaired the damage caused. Reforms in 1990 expanded the catalogue of youth sanctions to include mediation, community service, and social training courses among others (Dünkel, 2016b). Victim-offender-reconciliation has become a significant sanctioning practice in the German youth courts. More than one-third of all juvenile and young adults' cases are disposed of through a restorative sanction such as victim-offender-reconciliation or community service (Dünkel, 2016a, p. 703). This includes repaying victims through labor or even direct compensation, in which the young person's income is taken into account.

According to the JGG, when a young person is confined, it should "arouse the youth's sense of self respect," "be structured in an educational manner," and "help the 
Table 2. Minimum and maximum lengths of imprisonment for juveniles and young adults in Germany.

\begin{tabular}{lll}
\hline Youth Court & \multicolumn{1}{c}{ Regular offenses } & \multicolumn{1}{c}{ Very serious offenses } \\
\hline 14- to 17-year-olds & $\begin{array}{l}\text { Minimum is } 6 \text { months } \\
\text { Maximum is } 5 \text { years } \\
\text { Maximum is } 10 \text { years }\end{array}$ & Maximum is 10 years \\
$\begin{array}{l}\text { 18-, 19- and 20-year-olds (sentenced } \\
\text { according to JGG) }\end{array}$ & $\begin{array}{l}\text { Maximum is } 10 \text { years } \\
\text { Maximum is } 15 \text { years for an aggra- } \\
\text { vated murder offense }\end{array}$ \\
\hline
\end{tabular}

youth to overcome those difficulties which contributed to his commission of the criminal offense" (Youth Courts Law (Jugendgerichtsgesetz), 2008). As shown in Table 2, the minimum and maximum length of imprisonment that the youth court can order varies between 14- to 17-year-olds and 18- to 20-year-olds, and also between regular offenses and very serious offenses (the latter being those for which the adult criminal sentence is over 10 years imprisonment) (Dünkel, 2016b; Rap \& Weijers, 2014, p. 93). Fewer than $1 \%$ of young people receive sentences of 5-10 years, and fewer than $5 \%$ receive sentences between 3 and 5 years (Schiraldi, 2018c).

A prison sentence is executed in a juvenile facility for every young adult up to 24 years of age who receives a juvenile sentence (Rap \& Weijers, 2014, p. 94). Under Section 114, JGG, even young adults up to 24 years of age who have received a sentence of imprisonment under adult criminal law may serve their sentence in a juvenile facility, a provision that is being applied more often due to declining numbers in juvenile facilities. In order for youth imprisonment to be ordered, one of two preconditions must be met: either the "dangerous tendencies" of the youth exclude community sanctions as appropriate or there is "gravity of guilt" concerning particularly serious crimes such as murder or aggravated robbery (Dünkel, 2016b).

Despite the fact that young people in Germany tend to be incarcerated for more violent offenses than youth in US juvenile facilities, the treatment and living conditions of incarcerated young adults are very much normalized. For example, in Neustrelitz Youth Prison, there is an extensive vocational program including professional woodworking, metal working, culinary instruction and farming, with no use of solitary confinement or strip searching (Schiraldi, 2018c).

Germany records convictions and sentences in a Federal Crime Register. However, the records of juveniles and young adults up to 21-years-old who receive a juvenile sanction are not registered, with the exception of prison sentences (including suspended prison sentences) for over 1 year, which are recorded but whose access is restricted (Morgenstern, 2011, pp. 24-25). Furthermore, a Youth Court Judge can expunge the record on application by a juvenile or young adult no earlier than two years after completion of a sentence.

The German youth justice system is characterized by a high level of stability in terms of procedures and sentencing. This is despite the rhetoric in political debates sometimes being dominated by penal populism. For example, violent subway crimes in late 2007 led to the Christian Democratic Party (CDU) to call for increased juvenile sanctions, followed swiftly by a backlash from criminal justice practitioners and an election loss for the CDU in early 2008 (Dünkel, 2016a, p. 701). 


\section{The Netherlands: Applying and extending youth sanctions}

\section{Jurisdiction of the youth justice system}

A separate juvenile justice system (known as Kinderwetten or 'child laws') has operated in the Netherlands since the beginning of the 20th century, with sanctions and criminal proceedings intended to have a primarily "educative" or rehabilitative effect and a distinctive, child-friendly character (Weijers, 2017, p. 65). The minimum age of criminal responsibility is 12 -years-old.

The Netherlands has a flexible model, which allows for sanctions from the adult criminal code to be applied to juvenile defendants aged 16 or 17 , on the basis of either the seriousness of the offense, the personality of the defendant, or the circumstances under which the offense has been committed (Criminal Code, 2012, Art. 77.b.i). While the youth court judge can order an adult sanction, the case remains in the juvenile justice system where a youth court judge tries the case and the youth court procedures are followed during the trial (Rap \& Weijers, 2014, p. 92). Research has shown that adult custodial sanctions imposed on minors rarely exceed the maximum youth imprisonment sentence of two years (Criminal Code, 2012, Art. 77.i.1.b), and for very serious offenses hardly ever exceed eight years imprisonment (Rap \& Weijers, 2014, p. 92).

\section{Emerging adults in the justice system}

Proposals to introduce a separate young adult criminal justice system in the Netherlands began in the 1950s. In 1965, a bill was passed allowing the juvenile justice sanctions to be applied to "young adults" aged 18 to (but not including) 21. Efforts to further extend the upper limit to 23 gained traction by 2010 as a result of debates around brain research (uit Beijerse, 2016). Two reports in particular greatly influenced the debate: Juvenile and Young Adults: A Plea for Evidence Based Penal Law (Doreleijers \& Fokkens, 2010) and Juvenile Justice Processing: Future-Proof! (Council for Criminal Justice Application and Youth Protection (RSJ), 2011).

Despite previously touting a populist "tough on crime" stance, in June 2011 State Secretary of Security and Justice Fred Teeven presented a proposal to raise the age of youth sanctions to 23 (uit Beijerse, 2016). The main thrust of the arguments in support of the reform were that 15- to 23-year-olds are responsible for a disproportionately large share of crime, which must be combatted effectively with evidence-based, individualized youth sanctions, depending on the developmental phase of the offender (Marchena-Slot, 2017, p. 922).

The government drafted a bill based on neurobiological research findings that brain development is not complete in 18-year-olds, and that essential developments regarding impulse control, emotion management, plan-making and empathy may not be developed until 24 years of age (Winterdyk, 2014, p. 256). In the Explanatory Memorandum to the bill, it was noted that this ongoing brain development could be an explanation as to why a disproportionate number of young adults are involved in crime. By the time the legislation passed in 2014, there had been a progressive change in the ruling party. The 23-year-old age limit was maintained, and a provision 
Table 3. Summary of the jurisdiction and sanctions of the Youth Court and Criminal Court in the Netherlands.

\begin{tabular}{lll}
\hline Age at time of crime & Adjudicated by & Sanctions according to \\
\hline $12-15$ & Youth Court & Juvenile Justice \\
$16-17$ & Youth Court & Juvenile Justice \\
& Youth Court & Adult Criminal Law \\
$18-22$ & Criminal Court & Juvenile Justice \\
& Criminal Court & Adult Criminal Law \\
23 or older & Criminal Court & Adult Criminal Law \\
\hline
\end{tabular}

that would have doubled the maximum sentence for juvenile detention from 2 to 4 years was dropped from the bill.

As of April 2014, the Dutch Criminal Code now has a flexible sanction system for juveniles and young adults aged 16 to (but not including) 23 years, known as 'adolescentenstrafrecht' (adolescent criminal law) (Marchena-Slot, 2017, p. 922). No other country in Europe provides a legal basis for extending the use of juvenile justice provisions up to the age of 23 years. In practice, the reform raised the upper age limit for imposing youth sanctions from 21 to 23, and caused all system-involved young adults aged 18-23 to be assessed by the public prosecutor at an early stage of the process to determine whether or not they qualify for a youth sanction (uit Beijerse, 2016). Under the law, youth aged 18 and over are still dealt with by the adult criminal courts, and application of the adult criminal law by those courts is the default option. However, a recent site visit by the authors suggests that not all young adults subject to a youth sanction are dealt with by the adult criminal courts. In Rotterdam, the authors observed a practice by the prosecutor to send young adult offenders to the youth court (instead of the adult criminal court) if he or she determined that a youth sanction was suitable. A summary of the new sanction system is shown in Table 3.

The assessment by the public prosecutor on whether or not to apply youth sanctions relies on a social inquiry report into the system-involved youths prepared by the Dutch probation service on the social, emotional, and cognitive development of the young adult (Pruin \& Dünkel, 2015, p. 57). In specific cases, the public prosecutor may also rely only on a report prepared by the Dutch forensic psychiatry and psychology service (known as NIFP) assessing for mental health disorders. The prosecutors' decision is shaped by national guidelines (uit Beijerse, 2016). At the time of the reforms, many advocated for youths up to 23 years to originate in the youth court (similar to Germany). However, this was not considered feasible due to various stakeholder interests, including the fiscal incentive to keep cases in the adult courts. The courts in the Netherlands are financed according to the number of defendants appearing in court, and given that young adults represent a large proportion of criminal defendants, there was reluctance to transfer this group to the youth court and impact the funding (uit Beijerse, 2016).

Prior to adolescentenstrafrecht, it was possible for young adults between 18 and 21 to receive a youth sanction or measure under Article 77c of the Criminal Code (such as confinement in a juvenile facility) if the judge considered the personality of the offender and/or the circumstances under which the offense was committed as reason to do so. This provision was introduced in 1965, but was seldom used, and generally only in cases of young adults with mental disabilities (Rap \& Weijers, 2014, p. 94). The 
provision had to be exercised by adult court judges, many of whom appeared to be unaware of the provision's existence since it was located in the juvenile section of the Criminal Code (uit Beijerse, 2016). As was the case prior to the adolescentenstrafrecht reforms, the personality of the youths and/or the circumstances under which the offense was committed are still the same two considerations taken into account in determining whether or not a young adult qualifies for a sanction under the juvenile criminal law.

While the total number of criminal cases against 18- to 23-year-olds is decreasing, the application of juvenile criminal law to young adults is increasing as result of adolescentenstrafrecht. Prior to its introduction, the juvenile criminal law applied to fewer than approximately 160 young adult cases per year (or $1 \%$ of all criminal cases against young adults). After the legal change, the caseload increased to 400 cases per year (over $4 \%$ of all criminal cases involving young adults) (van der Laan, Beerthuizen, Barendregt, \& Beijersbergen, 2017, p. 4). The increase is mainly found in cases against 18- to 21 -year-olds (an increase from $0.9 \%$ receiving juvenile sanctions in 2014 to $7.3 \%$ in 2016). The application of juvenile criminal law applied to young adults ages 21 and 22 make up only a limited share of the increase $(1.1 \%$ received a juvenile sanction in 2016) (van der Laan, et al., 2017, p. 4).

In addition, the extension of the age range to age 23 appears to have affected the treatment of the 16- and 17-year-olds. Although the frequency by which they were prosecuted as adults was not high with only $2.1 \%$ of this age group having received adult sanctions in 2014, it has since declined further. In 2016, a mere $0.2 \%$ of 16 - and 17-year-olds received adult sanctions, a 90\% decline in 2 years. The reasons for this change appear to be two-fold. First, before the expansion of the youth justice system, 16- and 17-year-olds were considered older in the youth court and tended to foster a more serious response. Secondly, along with the change in law has come a greater understanding of impact of the justice system on adolescent development, including the benefits of juvenile rehabilitative services as well as the dangers of locking up children with older adults (Schiraldi, 2018a).

\section{Role of police, prosecutors, and the courts}

The Dutch approach is unique in that both the police and the prosecution have discretionary power and are legally entitled to dispose of cases (Weijers, 2017, p. 75). The police can dismiss a case and send a youth to a voluntary social support program or to the Child Care and Protection Board for further investigation. Alternatively, the police can issue a warning with no further action or impose a small fine in the case of a misdemeanour (Rap \& Weijers, 2014, p. 114). For minor offenses such as vandalism or shoplifting that do not require involvement of a prosecutor, police can also refer a juvenile up to 18-years-old to a community service project called HALT which carries out restorative "educational" and rehabilitative projects of up to $20 \mathrm{~h}$ for first-time offenders (Rap \& Weijers, 2014, p. 114; Weijers, 2017, p. 66). Finally, the police can send the charge to the prosecutor for further handling.

The prosecutor plays a central role in cases involving youth in the Netherlands. Every prosecution office in the Netherlands has designated youth court prosecutors 
and a public prosecutor's clerk that deals only with youth cases (Rap \& Weijers, 2014, p. 116). The prosecutor can decide whether to initiate court proceedings or determine that it is not expedient to prosecute a case. The prosecutor can also conditionally discharge cases that involve a misdemeanour or an offense punishable by a maximum of 6 years imprisonment. Since 2011, the prosecutor has the ability to establish the guilt of the defendant and order a sanction (including community service not exceeding $60 \mathrm{~h}$, a fine, the revocation of the right to drive motor vehicles, or probation of not more than 6 months on a juvenile defendant), and the defendant can appeal to the judge against that decision (Weijers, 2017, p. 67).

For youths, the prosecutor is in charge of the preliminary investigations and only when ordering pre-trial detention does a youth court judge hear the case in chambers and determine any pre-trial interventions (Rap \& Weijers, 2014, p. 127). Juvenile defendants are heard by one youth court judge, or in more serious cases a panel of three judges, one of whom must be a youth court judge. When the prosecutor intends to try the youth in court, the judge is legally obliged to ask for a social investigation report from the Child Care and Protection Board, which will include a recommendation concerning the most appropriate sanction (Rap \& Weijers, 2014, p. 132).

\section{Diversion, confinement, and other penalties}

A judge may impose penalties including juvenile confinement up to a maximum of 1 year for 12- to 15-year-olds or 2 years for 16 -years-and-over, up to $100 \mathrm{~h}$ of community service, or a fine of up to $4000 €$ (Weijers, 2017, p. 67). In recent decades, the maximum penalties for juvenile offenders have increased, but many less punitive sanctions have also been added. In addition, the judge may choose from a variety of alternative measures, such as placement in a behavioral institution, which can be extended up to a maximum of 7 years, though this has become associated with social stigma in the Netherlands due to the perception of requiring treatment for a "disorder" (Weijers, 2017, p. 67).

More young adults are now receiving the "educational" options under the juvenile law, including specialized probation caseloads and rehabilitative programming. Unfortunately, due to a change in state versus local funding for juvenile programs enacted in 2015, some are concerned that the impact of the adolescentenstrafrecht is being limited due to the eligibility and accessibility of these programs (Schiraldi, 2018a).

For young adults, the implementation of the juvenile confinement sentence can either take place in a juvenile institution or an adult prison (Rap \& Weijers, 2014, p. 94). From April 2014 to March 2015, 252 young adults were transferred from adult prisons to the juvenile institutions on the basis of the adolescentenstrafrecht reform (uit Beijerse, 2016). Minors up to 16-years-old in juvenile confinement spend most of their day in school and in small groups, based on a pedagogical system of supervision (Weijers, 2017, p. 64).

Legislation passed in 2001 (known as the Youth Justice Institutions Act or YJIA) regulates the legal position of young people in confinement (including detailed descriptions of which grounds and by whom a young person may be prevented from exercising his/her fundamental rights) (Weijers, 2017, p. 64). The YJIA establishes an 
elaborate system for filing complaints for violations, an appeals procedure, and an independent Supervisory Committee of legal experts and behavioral scientists. The YJIA also provides that any decision to use coercion or the imposition of disciplinary measures on youth in juvenile confinement must be made by management, rather than the correctional officers (Weijers, 2017, p. 64). Similar legislation and regulations were adopted by Germany in 2007.

In the Netherlands, all criminal convictions and sanctions are kept in a register (the Judicial Documentation System) for 30 years after the criminal sentence has become irrevocable, not including diversionary measures issued by police, such as a referral to the HALT program referred to earlier (Boone, 2011, p. 71). Public and private employers cannot access the records in the Judicial Documentation System; however, they can request a "Conduct Certificate," which is a statement by the Minister of Justice that there are no objections to the individual practicing a certain profession or fulfilling a certain position. The period of time considered in issuing a Conduct Certificate is usually limited to the previous four years (Boone, 2011, p. 76).

The number of juvenile institutions has decreased dramatically from 15 facilities with 2600 beds in 2007, to only seven facilities in 2018, including three centers operated by the Custodial Institutions Agency and four private youth facilities with approximately 500 beds in total (Ministerie van Justitie en Veiligheid, 2018; Weijers, 2017, p. 64). Juvenile institutions are now under review nationwide, with the intention to switch to a customized system of local, small-scale facilities located near the juveniles' own social network, combined with a few national facilities with specialist care and higher security. A small-scale pilot shelter was launched in Amsterdam in 2016 providing places for juveniles who attend school and/or work during the day and return to the shelter in the evening and on weekends (Weijers, 2017, p. 65).

\section{Croatia: Providing special procedures and assessing maturity}

\section{Jurisdiction of the youth justice system}

From its inception, Croatia's youth justice system has sought to employ the "welfare model," prioritizing measures with an underlying "educational" or rehabilitative function to prevent recidivism (Dolezal, 2017, p. 97). The 1918 Decree of the Vice-Roy of Croatia, Slavonia, and Dalmatia on the Punishment and Protection of Youth established: (1) a special procedure for dealing with juvenile offenders, (2) special court departments,

(3) court monitoring of the enforcement of educational measures, and (4) a minimum age of criminal responsibility at 14 (Bojanić, 2010, p. 187; Dolezal, 2017, p. 95).

In 1929, the Kingdom of Yugoslavia adopted a Criminal Code and Criminal Procedure Act which contained several provisions of the Decree of 1918, and further outlined three categories of young offenders: children under 14, young juveniles aged 14-16, and older juveniles from the age of 17 up to 21 . However, older juveniles were still treated in the same manner as adult offenders with the exception that they had less harsh mandatory sentences (Bojanić, 2010, p. 188).

In 1959, the Criminal Code was amended so that juvenile and "young adults" up to 21 were separated from more mature adults, based on an increasing awareness of social pedagogy, psychology, criminology, and criminal policy. A new system for 
Table 4. Summary of the jurisdiction and sanctions of the Criminal Court in Croatia.

\begin{tabular}{|c|c|c|}
\hline Age at time of crime & Adjudicated by & Sanctions according to \\
\hline $14-17$ & $\begin{array}{l}\text { Criminal Court (with special juve- } \\
\text { nile procedure) }\end{array}$ & Juvenile Justice \\
\hline \multirow[t]{3}{*}{$18-21$} & $\begin{array}{l}\text { Criminal Court (with special juvenile } \\
\text { procedure if younger than } 23 \text { at time } \\
\text { of trial) }\end{array}$ & $\begin{array}{l}\text { Juvenile Justice (if younger than } 23 \text { at } \\
\text { time of trial) }\end{array}$ \\
\hline & $\begin{array}{l}\text { Criminal Court (with special juvenile } \\
\text { procedure if younger than } 23 \text { at time } \\
\text { of trial) }\end{array}$ & Adult Criminal Law \\
\hline & Criminal Court & Adult Criminal Law \\
\hline 21 or older & Criminal Court & Adult Criminal Law \\
\hline
\end{tabular}

sanctioning youth was introduced, with community-based rehabilitative responses (or "educational measures") seen as the favored response and imprisonment seen as an extraordinary sanction (only to be applied to those aged 16 and above in exceptional cases) (Bojanić, 2010, p. 188).

Despite experiencing an increase in juvenile crime during the Croatian War of Independence from 1991 to 1995, Croatia did not respond by imposing more punitive responses (Dolezal, 2017, p. 97). In March 1993, the Commission for the Development of Criminal Legislation of the Republic of Croatia proposed to develop a separate, comprehensive law on the legal status of system-involved youths. The Croatian Youth Courts Act working group looked to other European countries (particularly Germany) and recommendations by the UN and Council of Europe in drafting the law (Bojanić, 2010, p. 188). This led to the Croatian Juvenile Courts Act 1997 (CYCA) which: (1) prioritized nonjudicial forms of intervention except where rehabilitative purposes could not be achieved or serious offenses had been committed; (2) established a series of "off ramps," first to prosecution through diversion, followed by alternatives to confinement through educational measures like counseling, community service, juvenile probation, special "orders" (conditions), day treatment, placement in open community settings (i.e., group homes), or short-term confinement; (3) introduced specialized judges, jurors and prosecutors for juveniles and young adults in the courts; and (4) legally defined the role of the "non-legal professionals" including social pedagogues, social workers, and psychologists who worked with the courts in dealing with juvenile and young adults, including advising the judge or prosecutor on psychosocial or criminological characteristics of the youth and monitoring the implementation of all sanctions (Dolezal, 2017, p. 98).

Under Croatian law, youths are not subject to prosecution until their 14th birthday and special youth provisions extend to the 21st birthday (Criminal Code, 2011). A summary of the jurisdiction and sanctions available to youth in the Criminal Court is shown in Table 4.

\section{Emerging adults in the justice system}

For decades before the enactment of the CYCA in 1997, young adults have had a special position in Croatian criminal law where they could be sanctioned as juvenile offenders. Article 2 of the CYCA defines a young adult as a person who at the time of committing a criminal offense is 18, but not yet 21-years-old (Bojanić, 2010, p. 189). 
The juvenile court procedure and sanctions can apply to a youth up to the age of 23 at trial.

For young adults, the court is to consider whether the youth's rehabilitation and prevention of further offenses can be better achieved by juvenile justice sanctions (Pruin \& Dünkel, 2015, p. 49). When determining the appropriate sanction, the court will pronounce a juvenile sanction when it can be concluded that the type of offense and the manner in which it was committed was a demonstration of the youth's age, and that the circumstances related to his or her personality justify the imposition of an "educational" or rehabilitative measure or juvenile imprisonment (Bojanić, 2010, p. 212). The sanction options available to the court are the educational measure of "special obligations" mentioned below, increased surveillance, or juvenile imprisonment. In the case of youths under 21 at the time of trial, the courts can also impose an "institutional educational measure," such as a referral to a residential center that focuses on education and vocational training (Pruin \& Dünkel, 2015, p. 49). The educational measures are not to continue beyond the young adult's 23rd birthday. Also, once a person has turned 21, they cannot be tried for an offense committed before the age of 16 (Pruin \& Dünkel, 2015, p. 50).

Convicted juveniles and young adults serve sentences in juvenile-specific prisons until they reach the age of 23 (Bojanić, 2010, p. 216). Juvenile incarceration of young adults cannot exceed 10 years. If the sentence has not been served at their $23 \mathrm{rd}$ birthday, they are transferred to an adult prison. In exceptional cases, a person who reaches the age of 23 while in prison may remain in the juvenile prison if it is deemed necessary for him or her to complete his or her educational or vocational training, or if the remainder of the sentence is no longer than 6 months. The maximum time at which a person must be transferred or released from a juvenile prison is 27 (Bojanić, 2010, p. 217). For young adults, judges appear to use juvenile sanctions infrequently in cases that involve incarceration compared to cases involving community-based alternative sanctions (Croatian Bureau of Statistics, 2017; p. 158; Schiraldi, 2018b).

If the young adult is 21 at the time of trial, they can receive a regular imprisonment sentence in place of juvenile imprisonment (Pruin \& Dünkel, 2015, p. 50). Where a young adult at the time of trial has already turned 23, the court will impose a regular sentence of imprisonment instead of juvenile imprisonment (despite the fact that the offense was committed when they were under 21) (Bojanić, 2010, p. 212). Where the regular criminal law is applied to a young adult, the court is not bound to impose the least severe measure of punishment for that particular criminal offense, but the sentence can be mitigated within certain limits prescribed by the Criminal Code (Bojanić, 2010, p. 212; Pruin \& Dünkel, 2015, p. 50).

\section{Role of police, prosecutors, and the courts}

There are no special, distinct courts for juvenile and young adults, rather, there are special procedures and departments housed within the regular municipal courts (Bojanić, 2010, p. 189). Only municipal courts in larger towns have youth departments (21 in total) (Caric, 2007, p. 45). The judges and public prosecutors (known as State's Attorneys) that staff the youth departments are required to have strong inclinations 
toward upbringing, an understanding of the needs of children and youth, and a basic knowledge of criminology, social pedagogy, and social welfare for young persons (Marsavelski, 2012, p. 4).

The network of nonlegal professionals, including social workers and psychologists, that are based within the court systems advise courts and prosecutors on developmental issues pertaining to juveniles and young adults. These nonlegal professionals not only interview and provide recommendations to the courts and prosecutors, but they also stay with cases postsentencing to check up on whether the court's orders are being followed and to arrange for postsentencing follow-up hearings, if necessary (Schiraldi, 2018b).

\section{Diversion, confinement, and other penalties}

Under Croatian law, the main purpose of juvenile sanctions is to educate young people, develop their overall personality, and to strengthen their sense of personal responsibility, which has led to the development of a variety of restorative measures. For example, the CYCA allows the State's Attorney to decide not to initiate criminal proceedings based on the willingness of the juvenile or young adult to take part in what is known as "special obligations," such as compensation, community service, vocational training, participation in rehabilitation, or taking part in youth counselling (Bojanić, 2010, p. 195). An additional option of an out-of-court settlement through mediation is available, which involves the youth taking responsibility and making amends with the victim. From 1998 to 2010, 35-45\% of juvenile cases (up to age 18) that have come to the office of the State's Attorney have been resolved through this out-of-court settlement (known as a conditional opportunity) (Dolezal, 2017, p. 99).

After the system-involved youth has fulfilled his or her obligations under supervision of the Center for Social Care, the State's Attorney makes the final decision whether or not to initiate criminal proceedings (Bojanić, 2010, p. 196). While the overall quantity of juvenile crime from 2000 to 2009 increased slightly, the same data showed that the types of sanctions imposed did not change, with $97 \%$ of all sanctions against convicted juveniles amounting to "educational measures" and rehabilitative services, and juvenile incarceration constituting <1\% (Dolezal, 2017, p. 105). The majority of system-involved youth are dealt with by diversionary measures as a direct consequence of the long recognized "principle of purposefulness" (Marsavelski, 2012, p. 6) allowing the prosecution and the police a wide degree of discretion (Dünkel, 2016 a, p. 702). In $2012,75.2 \%$ of youth ages $14-18$ and $26.8 \%$ of youth ages $18-21$ were diverted (Marsavelski, 2012, pp. 9-10).

The court has the option to impose formal sanctions, including "educational measures," safety measures (such as compulsory treatment for substance abuse), and juvenile imprisonment (Bojanić, 2010, p. 196). The CYCA sets out a list of sanctions (see Article 6-31), stating the criteria for each sanction and when and how they can be applied (Dolezal, 2017, pp. 99-100). For example, youth who were under 16 at the time of the alleged criminal act may receive only "educational measures" and not a safety measure or juvenile imprisonment. During the implementation of these measures, every 6 months the Court must consider whether there are any grounds to 
change or modify the plan. "Educational measures" may last no longer than the juvenile's 23rd birthday, and the maximum juvenile imprisonment term is 5 years (minimum is 6 months), or 10 years for certain criminal offenses (Bojanić, 2010, p. 199). Under the CYCA, imprisonment is used very rarely, with an estimated total of 20-30 juveniles and young adults in youth prisons in all of Croatia (Schiraldi, 2018b). No sanctions prescribed for adult offenders under the regular criminal law can be imposed on juveniles under 18 (Caric, 2007, p. 59). In addition, records of youth handled under juvenile law are always confidential.

Generally, only $8-10 \%$ of young adult offenders are sentenced to juvenile sanctions, mostly suspended juvenile imprisonment or "educational measures" (community-based rehabilitative services) (Pruin \& Dünkel, 2015, p. 50). In about $70 \%$ of all young adult convictions, a suspended adult prison sentence is applied, compared to $74 \%$ of all convictions for adults 21 and older (Pruin \& Dünkel, 2015, p. 51). The fact that a suspended prison sentence is so often applied and that the application of juvenile sanctions is used so sparingly is likely because the former is less intrusive than the "educational sanctions" and more rehabilitative responses for juveniles.

\section{Conclusions}

As the diverse states of Connecticut, Illinois, Massachusetts, and Vermont consider becoming the first US states to extend their juvenile courts' jurisdictions beyond age 18, we examined practices in Europe, which has much more experience with developmentally distinct approaches to emerging adults, for examples of how such changes can be enacted. Croatia, Germany, and the Netherlands have extended their juvenile laws to include youth age 18 and above each in distinct ways fitting their history and culture. While those countries have distinct approaches to which courts, which facilities and at which ages emerging adults can benefit from juvenile laws and practices, they also have some commonalities worth examination by US policy-makers. These generally include (1) greater reliance on informal approaches to offending by juveniles and emerging adults; (2) higher minimum ages at which juvenile laws can be applied to children; (3) greater reliance on "educational" - or rehabilitative - approaches to youth found involved in delinquent or criminal behavior; (4) greater confidentiality protections for youth and young adults; and (5) less reliance on incarceration, either in adult or juvenile facilities, as a sanction for criminal behavior. It is appropriate for the United States to seriously consider adopting these strategies.

\section{Acknowledgements}

The authors would like to thank Elizabeth Clark, Joshua Dohan, Frieder Dünkel, Ralph Grunewald, Neven Ricijaš, Jolande uit Beijerse and André van der Laan for reading an early draft and providing feedback. The authors also want to express their appreciation to Open Philanthropy for all their support of our research on system-involved emerging adults.

\section{Disclosure statement}

No potential conflict of interest was reported by the authors. 


\section{Notes on contributors}

Sibella Matthews is an Australian attorney and second-year Masters in Public Policy student at the Harvard Kennedy School.

Vincent Schiraldi is a Senior Research Scientist at the Columbia School of Social Work and CoDirector of Columbia University's Justice Lab.

Lael Chester is the Director of the Emerging Adult Project at Columbia University's Justice Lab.

\section{References}

An act relating to jurisdiction over delinquency proceedings by the Family Division of the Superior Court. (2016). Pub. L. No. No. 153.

Bojanić, I. (2010). Croatia. In F. Dünkel, J. Grzywa, P. Horsfield, \& I. Pruin (Eds.), Juvenile justice systems in Europe: Current situation and reform developments. (pp. 187-222). Mönchengladbach: Forum Verlag Godesberg.

Boone, M. (2011). Judicial rehabilitation in the Netherlands: Balancing between safety and privacy. European Journal of Probation, 3(1). (pp. 63-78). Retrieved from http://www.ejprob.ro/ index.pl/judicial_rehabilitation_in_the_netherlands_balancing_between_safety_and_privacy

Bryan-Hancock, D. C., \& Casey, S. (2010). Psychological maturity of at-risk juveniles, young adults and adults: Implications for the justice system. Psychiatry, Psychology and Law, 17(1), 57-69. Retrieved from https://doi.org/10.1080/13218710903268006

Campaign for Youth Justice. (2016, June). The impact of "Raise the Age" laws. Retrieved from http://www.campaignforyouthjustice.org/images/factsheets/ RTAlmpactTwoPagerJune72016final.pdf

Caric, A. (2007). The juvenile justice system in Croatia. In G. Giostra \& V. Patanè (Eds.), European juvenile justice systems (pp. 39-66). University of Macerata, Italy, Giuffrè Editore.

Chester, L., \& Perker, S. S. (2017). Emerging adults: A distinct population that calls for an ageappropriate approach by the justice system. Cambridge, MA: Program in Criminal Justice Policy and Management.

Clarke, E. (2015, March 17). Germany's 'Normalized' juvenile facilities a success. Retrieved from http://jjie.org/2015/03/17/op-ed-germanys-normalized-juvenile-facilities-a-success/

Council of Europe Committee of Ministers. (2003). Recommendation Concerning New Ways of Dealing with Juvenile Delinquency and the Role of Juvenile Justice $(\operatorname{Rec}(2003) 20)$.

Council for Criminal Justice Application and Youth Protection (RSJ). (2011). Jeugdstrafproces toekomstbestendig! Den Haag: RSJ. Retrieved from https://www.rsj.nl/binaries/rsj-bw-advies-jeugdstrafproces-toekomstbestendig-14-maart-2011_tcm26-26854.pdf

Criminal Code. (2011). Croatian Parliament. Retrieved from http://www.mvep.hr/files/file/dokumenti/prevodenje/zakoni/kazneni-zakon-nn-125-11-eng.pdf

Criminal Code. (2012). Kingdom of the Netherlands. http://www.legislationline.org/documents/ section/criminalcodes/country/12

Croatian Bureau of Statistics. (2017). Adult perpetrators of criminal offenses, reports, accusations and convictions (Statistical Reports 1605/2017). Croatian Bureau of Statistics, Zagreb.

Dolezal, D. (2017). Croatia: From welfare to responsibility. In Elaine Arnull \& Darrell Fox (Eds.), Cultural perspectives on youth justice: Connecting theory, policy and international practice (pp. 87-108). London: Palgrave Macmillan, UK.

Doreleijers, T. A. H., \& Fokkens, J. W. (2010). Minderjarigen en jongvolwassenen: Pleidooi voor een evidence based strafrecht. Rechtstreeks, 2, 8-47.

Dünkel, F. (2016a). Juvenile justice and human rights: European perspectives. In H. Kury, S. Redo, \& E. Shea (Eds.), Women and children as victims and offenders: Background, prevention, reintegration: Suggestions for succeeding generations (Vol.2, pp. 681-719). Cham: Springer International Publishing: Imprint: Springer. Retrieved from http://nrs.harvard.edu/urn-3:hul. ebookbatch.SPRGR_batch:9783319284248 
Dünkel, F. (2016b). Youth Justice in Germany. https://doi.org/10.1093/oxfordhb/9780199935383. 013.68

Dünkel, F., \& Heinz, W. (2017). Germany. In S. H. Decker \& N. Marteache (Eds.), International handbook of juvenile justice (2nd ed., pp. 305-326). Cham, Switzerland, Springer. Retrieved from http://www.springer.com/us/book/9783319450889

Federal Trade Commission. (2013, September 23). Alcohol laws by state. Retrieved April 24, 2018, from https://www.consumer.ftc.gov/articles/0388-alcohol-laws-state

Giedd, J. N., Blumenthal, J., Jeffries, N. O., Castellanos, F. X., Liu, H., Zijdenbos, A., ... Rapoport, J. L. (1999). Brain development during childhood and adolescence: A longitudinal MRI study. Nature Neuroscience, 2, 861-863. https://doi.org/10.1038/13158

Howell, J. C., Feld, B. C., Mears, D. P., Farrington, D. P., Loeber, R., \& Petechuk, D. (2013). Bulletin 5: Young offenders and an effective response in the juvenile and adult justice systems: What happens, what should happen, and what we need to know (Study Group on the Transitions between Juvenile Delinquency and Adult Crime No. Grant Number 2008-IJ-CX-K402). Final report to National Institute of Justice.

International Centre for Prison Studies. (2010). Young adults and criminal justice: International norms and practices. King's College London. Retrieved from https://www.t2a.org.uk/wp-content/uploads/2016/02/T2A-International-Norms-and-Practices.pdf

Ishida, K. (2015, February). Young adults in conflict with the law: Opportunities for diversion. Retrieved September 7, 2017, from http://jjustice.org/wordpress/wp-content/uploads/YoungAdults-in-Conflict-with-the-Law-Opportunities-for-Diversion.pdf

Loeber, R., Farrington, D. P., \& Petechuk, D. (2013). Bulletin 1: From juvenile delinquency to young adult offending (Study Group on the Transitions between Juvenile Delinquency and Adult Crime No. Grant Number 2008-IJ-CX-K402). Final report to National Institute of Justice.

Marchena-Slot, A. (2017). Juvenile justice and adolescence: A comparison within the Kingdom of the Netherlands. In T. Liefaard \& J. Sloth-Nielsen (Eds.), The United Nations Convention on the Rights of the Child: Taking stock after 25 years and looking ahead (pp. 913-927). Leiden and Boston: Brill/Nijhoff.

Marsavelski, A. (2012). Alternatives to custody for young offenders. International Juvenile Justice Observatory. Retrieved from http://www.oijj.org/sites/default/files/baaf_croatia1.pdf

Ministerie van Justitie en Veiligheid. (2018, January 5). Justitiële Jeugdinrichtingen. Retrieved April 12, 2018, from https://www.dji.nl/locaties/justitiele-jeugdinrichtingen/index.aspx

Monahan, K. C., Steinberg, L., Cauffman, E., \& Mulvey, E. P. (2009). Trajectories of antisocial behavior and psychosocial maturity from adolescence to young adulthood. Developmental Psychology, 45, 1654-1668. https://doi.org/10.1037/a0015862

Monahan, K., Steinberg, L., \& Piquero, A. R. (2015). Juvenile justice policy and practice: A developmental perspective. Crime and Justice, 44(1), 577-619. https://doi.org/10.1086/681553

Morgenstern, C. (2011). Judicial rehabilitation in Germany - The use of criminal records and the removal of recorded convictions. European Journal of Probation, 3(1), 20-35.

National Conference of State Legislatures. (2017, July 28). Extending foster care beyond 18. Retrieved April 24, 2018, from http://www.ncsl.org/research/human-services/extending-fostercare-to-18.aspx

Piquero, A. R., Farrington, D. P., \& Blumstein, A. (2003). The criminal career paradigm. Crime and Justice, 30, 359-506. https://doi.org/10.1086/652234

Pruin, I., \& Dünkel, F. (2015). Better in Europe? European responses to young adult offending. Universitat Greifswald: Transition to Adulthood. Retrieved from https://www.t2a.org.uk/ research/better-in-europe-european-responses-to-young-adult-offending/

Rap, S., \& Weijers, I. (2014). The effective youth court: Juvenile justice procedures in Europe. The Hague, The Netherlands: Eleven International Publishing.

Robinson, M. (2018, April 20). Where you can legally smoke marijuana in the US in 2018. Retrieved April 24, 2018, from http://www.businessinsider.com/where-can-you-can-legallysmoke-weed-2018-1

Sampson, R. J., \& Laub, J. (2003). Life-course desisters? Trajectories of crime among delinquent boys followed to age 70. Criminology, 41, 555-592. https://doi.org/10.1111/j.1745-9125.2003.tb00997.x 
Schiraldi, V. (2018a, March 27). Raising age to 23: It works for the Dutch. Retrieved April 24, 2018, from https://thecrimereport.org/2018/03/27/raising-juvenile-age-to-23-produces-promisingresults-for-dutch-us-researchers/

Schiraldi, V. (2018b, April 4). How Croatia's 'Off-Ramps' keep young adults out of prison. Retrieved April 24, 2018, from https://thecrimereport.org/2018/04/04/how-croatias-off-ramps-keepyoung-adults-out-of-prison/

Schiraldi, V. (2018c, April 10). In Germany, it's hard to find a young adult in prison. Retrieved April 24, 2018, from https://thecrimereport.org/2018/04/10/in-germany-its-hard-to-find-a-youngadult-in-prison/

Schiraldi, V., Western, B., \& Bradner, K. (2015). Community-based responses to justice-involved young adults (New Thinking in Community Corrections Bulletin). Laurel, MD: U.S. Department of Justice, Office of Justice Programs, National Institute of Justice. Retrieved from https://purl. fdlp.gov/GPO/gpo83079

State of Vermont. (2016). An act relating to jurisdiction over delinquency proceedings by the Family Division of the Superior Court. H.95 (Act. 153).

uit Beijerse, J. (2016). The new Dutch law and policy on young adult offenders. Euro Vista Probation and Community Justice, 4. Retrieved from http://www.euro-vista.org/eurovista-vol-42/

United Nations Office of Drugs and Crime. (2013). Justice in matters involving children in conflict with the law: Model law on juvenile justice and related commentary. United Nations, Vienna.

van der Laan, A., Beerthuizen, M., Barendregt, C., \& Beijersbergen, K. (2017, September 1). Adolescent criminal law: Policy theory and first empirical finding. Retrieved September 26, 2017, from https://www.wodc.nl/onderzoeksdatabase/2460d-evaluatie-wet-adolescentenstrafrecht. aspx

Weijers, I. (2017). Children and the law in the Netherlands: A comparative introduction. The Hague, The Netherlands: Eleven International Publishing.

Willrich, M. (2003). City of courts: Socializing justice in progressive era Chicago. UK: Cambridge University Press.

Winterdyk, J. A. (2014). Juvenile justice: International perspectives, models and trends. Boca Raton, FL, CRC Press.

Youth Courts Law (Jugendgerichtsgesetz). (2008). German Federal Law Gazette. Retrieved from https://germanlawarchive.iusQ14comp.org/?p.756 